\title{
Adult Education in Small States: the case of Malta
}

\section{Peter Mayo, Paul J. Pace and Edward Zammit}

This is an accepted manuscript of an article published by Taylor \& Francis in Comparative Education Vol. 44, No.2, 2008, pp 229-246 Available at:

http://www.tandfonline.com/doi/abs/10.1080/03050060802041746\#.VQdGco6GPU4

\section{Introduction}

This paper focuses on the situation of and challenges facing a small state in the field of adult education and training. The first section provides some general considerations regarding the situation of adult education in Malta, emphasising the link between the issues raised and Malta's small state condition. This opening section is therefore general in scope and it is hoped that the points made resonate with the experiences of adult educators in other small states (including micro-states), hopefully adding to the paucity of literature that exists on the topic. The broad sweep of the first section gives way to the more focused analyses of the second and third sections, based on a selection of just two topics from among the many (the first section attempts to do justice to the range of issues as derived from the Maltese situation) that affect adult education in small states. The second section will focus on the ever so pertinent area of adult education and work within the context of the small state's economic viability. The third and final section will focus on another area of concern for adult education in small states, namely adult education for sustainable development.

\section{The Broad Spectrum}

\section{Flexible specialisation, Multifunctionalism and Intimacy}


A conference held in Malta in 1995 highlighted some of the main issues concerning adult continuing education in small states. This was the first and to date only conference in the area, with a selection of papers published in a special issue of the ICAE $^{1}$ journal Convergence (Mayo and Briguglio, 2006). The majority of small states represented at the conference were 'developing nations' many of which, therefore, having a recent colonial past. This is hardly surprising since the majority (though not all) of small states share this characteristic. Many so called 'developing small-states' found it difficult to provide education for all in the short term and therefore adult education became a viable and cheaper alternative in this context (see for instance, Freire, 1976). In the conference papers, some perceived strengths and weaknesses of adult education in small-states were highlighted (see for instance Rogers, 1996, p. 11).

Among the features highlighted throughout the 1995 conference, in the context of adult education in small-states, were the multifunctional use of resources, limitations in expertise, retooling of labour, exposure to distance education provision and migration. All these apply to the small-state context under review. It is common knowledge that the cost per capita of services in small-states is higher than that of larger ones (Jules, 1994/5, p. 10). Duplication is therefore even more wasteful in such contexts (ibid) and there is often pressure to make multifunctional use of schools and other learning settings to maximize their potential and therefore prevent them from serving as idle capital for the best part of the day or for substantial periods during the year (Baldacchino and Mayo, 1996, p. 26). It is common to find schools serving as adult education centres in the evening in Malta, a situation shared with a number of other small states such as Cyprus (Symeonides, 1992, 2004) and many states of the Caribbean where schools and 
community centres are used for adult education and for a host of other social functions since the school is often the only major social infrastructure in rural communities which can host mass functions. ${ }^{2}$ In Malta, schools were conceived of, according to the 1999 National Minimum Curriculum document (Ministry of Education, 1999), as community learning centres, combining the teaching of schoolchildren in the morning with educational programmes for the rest of the community after conventional hours. The issue of maximizing resources by making multifunctional use of them (Farrugia and Attard, 1989; Farrugia, 2007, pp. 210, 211) was given prominence in the discussion around this concept (Mayo, 2004). As Didacus Jules argues, "Resource limitations (financial and human) make it necessary for really creative solutions to be examined that enable the small state to maximize the use of these resources and achieve more with less.” (in Borg and Mayo, 2007). One of the problems of using schools and other conventional learning sites for adult education purposes is that they might not constitute the appropriate learning setting for adults. Adult learners, appearing as "granddaddy longlegs" (Horton in Horton and Freire, 1990, 69), can easily consider this a throwback to their uninspiring schooldays. This would serve as a means to alienate potential adult learners from the adult learning centre. Adult education would represent 'adult schooling' and, if we can take liberties with the title of Illich and Verne's (1976) work, we would argue that the people involved would run the risk of being imprisoned in the community classroom.

\section{The Culture of Schooling}

The culture of schooling predominates in such contexts (see Baldacchino and Mayo, 1995), the more so when one considers that donor agencies tend to provide funding for developing the recipient country's formal system of education (Jules, 1994). ${ }^{3}$ 
Small states would therefore do well to help rectify this situation by conceiving of schools as multipurpose learning sites (Jules, 1994), equipped with different and flexible settings that can accommodate persons of different ages, providing each with a meaningful and not a domesticating education. The Maltese national curriculum proposes the idea of schools as community learning centres with this purpose in mind. It places the emphasis on an architectural setting that calls for imagination and new thinking with regard to the creation of publicly funded learning environments. The idea is still in its embryonic stage in Malta and it would be interesting to closely monitor further developments in this area to explore its wider and international relevance. This seems to be the way to go for small states to develop a cost effective, resource maximising educational infrastructure. In St. Lucia, for instance, Didacus Jules, in his capacity as Permanent Secretary for Education, advocated a new architecture for the school as community infrastructure that combines school, community library, internet facilities, auditorium, etc. This idea has been taken up in Trinidad \& Tobago where Dr Jules assisted with the new education strategy developed in this small island state. ${ }^{4}$

\section{Flexible specialisation}

It is common to find, in Malta, schoolteachers doubling up as adult educators, a situation which is typical of many other small states as, once again, the examples of Cyprus and the islands of the Caribbean bear out ${ }^{5}$ In these situations, and with respect to State sponsored provision, teachers are paid an honorarium for their additional adult education work. Mass constraints prevent small states from possessing all the specialists they require. The demand is often not large and constant enough to warrant the employment of full time personnel. In this respect, Jules (in Borg and Mayo, 2007, p. 128) is instructive: "there is a common tendency to lament the human resource 
deficiencies of ministries of education in small states and invariably administrators call for "more staff" to undertake vital functions. I have often argued that the challenge and the solution is not necessarily more staff but more capacity." This is most true of adult education. One needs to build and broaden the capacity of educators. For many educators, adult education is just one in a large range of educational roles to be performed. In Malta, educators might very well teach school children during the day, adult learners during the evening and foreign language students in the summer months. They often provide private tuition to boot (Falzon \& Busuttil, 1988). The problem with this situation is that teachers might replicate with adults the approaches they adopt with younger learners during conventional hours. The experience of one of the authors, who coordinated a government sponsored literacy programme in the early 90s (Mayo, 1994), tends to suggest, however, that generalisations of this type are dangerous. While some teachers appeared guilty of such replication, and research by Enriquez (1995) with regard to a morning access programme seems to confirm this, others were astute enough to adapt to the demands and aspirations of adult learners to be treated first and foremost as adults with a certain degree of responsibility, autonomy and experience. (Mayo, 2007, p. 24) This situation however places the emphasis on flexible-specialisation (Brock, 1988, p. 306) rather than overspecialisation. And resourceful people in small states are likely to pride themselves in being 'flexible' enough to adapt to different contexts and circumstances. Universities and other agencies concerned with the preparation and continuing professional development of educators need to take their cue from such people and provide programmes with the flexibility necessary for their graduates to learn to wear 
different hats well and adapt to the different educational groups with whom they are working, be they children or adults.

\section{Alternative sites of Adult Learning}

This situation applies to a variety of settings and not simply schools. Take Museums as an example. There are those who would regard them as potentially important assets for what in most small states constitutes a mainstay of the economy tourism, especially if one takes up the challenge to move from the seasonal 'beer belly, sun and sea tourism', typical of small island states such as Malta, and opt for cultural tourism which might prove to be less seasonal in the long run. These potential assets also require flexible specialisation if those who run them attempt to step up their act and provide a more encompassing service on the lines of some of the more interesting and yet perhaps less endowed museums (in terms of historical and other artefacts) in similar or even larger countries. Museums are increasingly being regarded as important sources of lifelong learning including adult learning (Chadwick and Stannett, 1995; 2000). Since museums in small states are small and employ an exiguous staff, their curators often need to combine their role as museum administrator with that of museum educator. This applies to most small museums (Hooper-Greenhill, 1995), irrespective of country size. It is difficult enough for such museums to employ a full time educator, let alone specialist educators (one targeting children and another targeting adults), given the limited amount of visitors involved. What they require in such contexts are educators who appeal to visitors of different ages. Any initial programme to help persons run museums efficiently must provide the broadest and most flexible museum preparation possible; this would include preparation to act as museum educators (Borg and Mayo, 2000). Flexible specialisation, incorporating the ability to provide an educational service, becomes a 
feature of museums which have enormous potential in serving as adult education agencies. Preliminary research on the limits and possibilities in this regard, with respect to Malta, is available (Borg and Mayo, 2001a; 2001b; Borg, Cauchi and Mayo, 2002).

\section{The Intimacy Factor}

Before one moves on to the more macro level issues concerning adult education in Malta, with their potential resonance with the experiences of other small states, there is one aspect of adult education provision that requires some consideration. It concerns the issue of intimacy and its management in a small state context. This takes many forms. The smallness of the localities in Malta can have a negative effect on participation in educational programmes, such as those of literacy and adult basic education, which carry a stigma. People do not like to be seen attending such classes (see Mayo, 1994) and the relative proximity and ease of reach of other localities often makes people prefer to commute to other towns and villages to attend classes there and thus escape the notice (and gossip) of their neighbours in the home town or village. This situation places the onus on adult education programme organisers to be creative and the best programmes seem to be those where community members are adult educators and adult learners at the same time, for example teaching popular cookery classes and attending literacy classes at the same centre, as in the case of the Paulo Freire Institute in the locality of Zejtun. ${ }^{6}$ Assuming the respectable status role of teacher or adult educator, in this context, compensates for or possible even renders palatable that of being an adult learner in a literacy class.

The issue of intimacy in a small state situation becomes most relevant in the context of prison education, which is given increasing importance in the international literature on adult education. ${ }^{7}$ While there is more to prison education than that of serving 
long term economic ends (see Calleja, 2006, in Mayo, 2007, p. 31), one of the challenges facing such an adult education provision in small states such as Malta is widely believed to be that of equipping inmates at the facility with skills that render them marketable after their release from prison and therefore employable, no mean task given the prejudice which is likely to accompany any application for employment on their part in a small island archipelago where people are easily well known. ${ }^{8}$ The general tendency internationally is to equip such persons with the skills to become self-employed and some University graduates who emerged from the correctional facility education programme in Malta have been very successful as self employed persons on release from prison. ${ }^{9}$ Another option would be to educate for the creation of cooperatives. These are some of the ways by which adult education programmes in prison can counter the most negative effects of the intimacy factor in small communities.

\section{Globalisation}

In addition to the foregoing, one must address the macro-level issue of globalisation and its impact on adult education in small states. An appreciable amount of literature has been written on the connection between globalisation and adult education and training (see, for instance, Walters, 1997). However the impact of globalisation on adult education in small states deserves some special consideration. Later sections will deal with education to retool labour, in light of the effects of the intensification of globalisation and the mobility of capital across borders, and environmental adult education in a small state context characterised by a small land mass where any environmental impact, including the impact of globalisation forces, is likely to be 
stronger and more visible than in larger states. There are some other important

considerations to be made with respect to globalisation's impact on the area.

\section{The Challenge to Monopolies}

One of these is the threat posed by foreign bodies to established monopolies that have for long been a characteristic of smaller states (Sultana and Baldacchino, 1994). Providers of adult continuing education opportunities are a case in point. In many small states, universities, traditionally important players in adult higher education, simply do not exist and where they do, they might only recruit those who can afford to pay. There is often an over-reliance on students moving abroad to regional centres, as in the South Pacific and Caribbean, and on adult learners availing themselves of distance learning opportunities when these are made available. In this age of liberalisation of services, in which efforts are being made through the contested and hitherto resisted GATS (de Siqueira, 2005; Hill and associates, 2005: 21-24; Verger and Bonal, 2006) to regard educational provision as a service and therefore to be made subject to liberalisation, distance/online education is becoming a potent global force for continuing education. This type of education, with its flexibility, individually tailored programmes and liability for yet another form of cultural invasion, occupies the space left vacant because of the inexistence of universities (potential providers of extension learning services and continuing education) in many small states. In Malta there is a university of long standing, an institution that traces its origins to 1592 . It has had its share of university continuing education but this has been sporadic (see Mayo, 2002). There has been an expansion post 1987 (change of political administration resulting in a change of policy for higher education) in the areas on offer as well as in the number of students attracted to the institution. Online learning agencies however serve to challenge the university's long 
held monopoly over the provision of courses, including extension studies courses. As in the case of Malta, and given their size, small states would hardly afford more than one university (although both Iceland and the Turkish Republic of Northern Cyprus, recognised only by Turkey, have several while the recognised Republic of Cyprus will soon have around five universities). This sole university therefore enjoys a monopoly in the area, especially in a context such as an island context where people cannot commute easily across national frontiers to pursue courses (e.g. people from San Marino can cross over to Bologna etc). This 400 year monopoly of the University of Malta is challenged by the globalising force of information technology with its various forms of online learning some of which leading to the acquisition of prestigious qualifications. This is particularly the case with postgraduate degrees which, at the University of Malta, are often offered part-time for the benefit of those adult students already in employment and where, in contrast to the mass-oriented undergraduate courses, enrolment is restricted; degree requirements often include thesis supervision by a potentially exiguous staff. Whereas in the past, many of those who did not manage to get into the programme were thwarted in their attempts to secure a higher degree (unless they had the wherewithal to travel and study abroad), in more recent years they have been availing themselves of the option of distance and online learning from abroad.

The University's monopoly has mainly been challenged by institutions who serve as franchise agencies for foreign universities and schools such as the Universities of London, Sheffield, Sheffield Hallam, Leicester, Anglia, Sunderland, and such schools as Henley's and Maastricht's School of Management. All these provide courses that would fall under the rubric of continuing professional development. And the pressures of such 
supranational organisations as the EU (which has facilitated the pursuit of foreign routes through the payment of local fees) for its member states to increase their quota of graduates, as underlined in the Lisbon objectives, are likely to induce the government of Malta to approve of the work of such alternative and foreign bodies. After all, they alleviate the burden of having to increase graduate numbers.

\section{Migration}

One other major impact of the intensification of globalisation is the effect it has on demographic shifts across territories. Certain small states have for so long been net exporters of labour power; Malta was no exception. This situation certainly had an effect on the country's adult education provision, the nature of which was conditioned by the demands of the receiving countries, for example the acquisition of basic literacy skills in the language of the receiving country (see Baldacchino and Mayo, 1996; Mayo, 2007, pp. $14,15)$. Malta is now a net importer of labour power - a net recipient of immigrants crossing over from other continents who land on the island, either by accident (at the behest of those who traffic in migrant transportation) or by design, since the country serves as first port of call. A frontier island such as Malta, with respect to the shores of North Africa, feels the pressure of such immigration. Racism and xenophobia, a characteristic of countries all over the world, irrespective of size, becomes writ large in a country which has a small land mass and is densely populated. There is the constant fear that the country is 'being swamped.' Add to that the fact Malta has had for years a very visible autochthonous population and experienced centuries of Eurocentric Christian domination which left a legacy on popular sensibilities, and one has the perfect recipe for 
ethnic tensions and xenophobic incidents (Borg and Mayo, 2006). The challenges for adult education in this context are twofold. In the first place, there is a need for a strong anti-racist adult education provision at all levels targeting various sectors of the population including journalists, judges, teachers, immigration officers, members of the armed and police forces (often overstretched given the size of the force and the constant inflow of immigrants), health workers etc. There is also a need to convert detention centres for immigrants into lifelong learning centres, in collaboration with larger foreign countries, including EU countries, who can help provide resources of learning that will enable many of the immigrants to resettle given the small size and population density of the small nation state (Borg and Mayo, 2006; Mayo, 2007, p. 57); it is frequently argued that a small state such as Malta cannot face this burden on its own.

Having highlighted some general considerations with regard to adult education in a specific small state context, we now provide a more in depth analysis of two key aspects of adult education provision in the same context, starting with the delicate though key area of adult education and work. This would hopefully serve as an illustrative case from which important considerations regarding the challenge of scale in this context can be derived. Furthermore each small state context has its own contextual specificity, and no attempt will be made to overlook this in our eagerness to shed light on possible characteristics of small states through the Maltese example.

\section{Adult Education and Work}

According to Baldacchino (1993) the services that have traditionally provided much of the revenue for developing small states such as Malta, whose status is that of a 'rentier state,' include tourism, transhipment, bunkering, offshore banking and the 
provision of yacht berths (p. 40). Many of these services apply to Malta whose economic structure has traditionally rested mainly on three pillars: manufacturing, tourism, and market services. These services highlight the open nature of the country's economy with its dependence on external forces. This places emphasis on the acquisition of knowledge, through initial and adult continuing education, as well as informal learning, that has a strong international currency, with strong implications for language learning (foreign language learning becomes a potentially important economic asset in such a context).

\section{Tourism}

Tourism is a characteristic of several small states especially island states with their constructed images of being 'idyllic' (e.g. Grenada being the 'happy isle'), 'exotic' (constructing another form of Orientalism, in Edward Said's terms?), 'romantic' (e.g. Cyprus being the island of Aphrodite and Love - Paphos, Ayia Napa), 'in close proximity to the sea', 'getting away from it all' places, and territories which can be covered in their entirety within a single trip. The seasonal aspect of tourism calls for great imagination and careful planning in this particular area with adult education having an important role to play here. If one is to move from the seasonal 'sun and sea' tourism to what is often referred to as 'quality' tourism then certain measures need to be taken.

One of the major challenges to be highlighted in the third section is that of sustainable development where the development of the tourism industry must be tempered by a certain sensitivity for the environment, since environmental degradation, fuelled among other things by a construction driven industry, serves to kill the country's major earner of foreign exchange, that is tourism itself. 
Furthermore there is the challenge to be faced in working to render the country's cultural heritage more palatable to tourists through adult education programmes. These programmes can contribute to enhancing the quality of tourist guides, creating software and other devices such as consoles that render historical sites more user friendly, and improving the repertoire (including the ability to act as museum educators) of personnel working inside these heritage sites and museums. In short these heritage and museum sites can be turned into lifelong learning sites that render any visit by tourists and locals a learning experience, the sort of experience one would associate with the less seasonal quality/cultural tourism.

\section{Outsourcing of Manufacturing Jobs - a 'No Go' area}

One of the three traditional pillars - manufacture - is being eroded. It is difficult to attract outsourcing since this requires labour intensive work and the 'numbers just do not add up' in small states. Globalisation and mobility of capital have rendered this traditionally important sector of the economy a non viable option. Export-led industrialisation propelled by foreign investment and technology is passé. The challenge for small states like Malta these days is to compete on higher value added, strong work ethic and reduced transport costs. The challenge is also that of engaging in strong and serious attempts to discover niche markets for indigenous industries with respect to history, culture, agriculture, food processing, wine and certain crafts.

\section{Knowledge Intensive Jobs}

The alternative and therefore challenge for adult education and training is to prepare and educate people for jobs which are not labour but knowledge intensive. There is a growing need for a shift from providing the sort of adult education and training geared for jobs in the manufacturing sector to adult education focusing on the New 
Literacies and new basic kills, as defined by the European Union, the latter constituting the first of the six key messages of its Lifelong Learning Memorandum (European Commission, 2000). ICT features prominently in the first of the six messages, to which we would add foreign language learning. Needless to say, the 'old literacies' such as basic literacy still remain a requirement for people to perform effectively in knowledge intensive jobs but it is equally obvious that one needs to move beyond these and embrace the areas just identified. In this respect, a report (Forum for a Better Economy, 1988) identified the following "weaknesses" in the Maltese labour force: weaknesses in life skills, literacy, numeric skills, I.T. and computer literacy.

If schools are to be developed as multipurpose learning sites, as suggested earlier, one must ensure that they are equipped with and allow flexible use of a whole range of learning resources (ICT and audiovisual equipment, etc) that allow for the acquisition of these skills, equipment which can be used by both children during conventional hours and adults, later, in a manner that prevents an expensive duplication of resources.

And the characteristic of 'flexible specialisation' which is required of most personnel functioning in small states, for reasons outlined in the first section, becomes all the more important and, if cultivated carefully and imaginatively, can prove to be an invaluable asset in this age characterised by the intensification of globalisation and mobility of capital. Some of the conclusions found in a Human Resources Policy and Strategy for Malta document (ETC, 2003) commissioned by the Employment and Training Corporation, include the following:

- A multi-skilled labour force is seen nowadays as a prerequisite for sustained economic growth. 
- Future workers will have to be psychologically prepared to adapt themselves, preferably in anticipation of changes in demand for skills.

Malta seems to have some of the institutions to cater for a shift in emphasis in adult vocational education with the establishment, in 1998, of the Night Institute for Further Technical Education (NIFTE), which falls under the Employment and Training Corporation, and the re-establishment of MCAST in 2000. NIFTE was set up through collaboration with the Ministry of Education, the Malta Development Corporation (now Malta Enterprise), the Federation of Industries and the Israeli organisation ORT-Union College for Sciences and Advanced Technologies (Cardona, 2000). The original intention was to involve several sectors of Maltese industry in offering their sites and facilities for the further technical training of adults, originally at no charge but expenses are now being charged on a cost recovery basis. The other major development is the reestablishment of the Malta College of Arts Science and Technology (MCAST), a vocational college with a strong adult education and training component. Then there is the impending Smart City development that entails the creation of an infrastructure for high tech companies to set up shop in Malta, a development which has obvious implications for adult education and training as provided by the established institutions such as the University and MCAST as well as the foreign agencies that make their presence felt in the commercial adult education scene.

\section{Monopoly Challenged Once Again}

As with university education, any monopoly in the field of adult training is now being challenged by an increasing number of foreign institutions which offer their services through local agents or through distance learning. Such services are invariably provided on a competitive, commercial basis. This infiltration into the 
local market is particularly felt in the area of ICT where the cost of educational equipment is affordable. Such courses appeal to local users because of their flexibility - often enrolling participants with minimal, initial qualifications. They also bank on the traditional attraction of foreign certification, which can be regarded as a reflection of the urge to acquire positional goods (signs of distinction) and possibly a colonial hangover.

The liberalisation of the international market of training and its effects on the local scene also connects with another feature of adult education and training in small states, namely the traditional reluctance of small and medium size enterprises, which constitute the vast majority of firms in a small state such as Malta, to set up their own training cycle because of their lack of economies of scale which renders the cost per capita of training employees prohibitive, a situation that is also compounded by the fact that the newly and expensively retrained employee can be poached. This is one of the reasons why investment in adult vocational education is, for the most part, the responsibility of the State, perhaps in partnership with industry, via its collective representative bodies, ETC and MCAST. But this reluctance of SMEs to set up their own training cycle also facilitates the encroachment of foreign bodies, with the required economies of scale, in various areas of CVT. They can pounce on any void left by local agencies.

The open nature of this provision, where the demand for adult education and training in small states is being filled from outside, calls for the establishment of a monitoring national body on the lines of the Commission for Higher Education set up in Malta for the higher education institutions. ${ }^{10}$ Such a body would logically, given 
the constraints of small states, also help to provide a modicum of direction to and coordination, as well as validation, of resources, especially in those areas where local players are involved, given, once again, that the cost of resource duplication in small states is very high indeed. Adult Education should be an important concern of this body in order to ensure that adequate standards are maintained. This development has important implications for an economy oriented adult education, particularly in areas like ICT and adult training or adult training and development.

\section{Workers' Education for Multifunctional Roles}

Finally there is more to adult education and work than simply education for employability which does not necessarily mean employment (Gelpi, 2002). There is a whole tradition of workers' education, including trade union education, which has to be taken into account. Organisers of this type of adult education must constantly bear in mind the small state dimension of the contexts in which different categories of workers are operating in Malta. Trade unionists in a small state like Malta also have to adopt multifunctional roles, as with other officials and administrators throughout the islands.

Even the largest union in Malta, the General Workers' Union (GWU), does not have the economies of scale of say a Transport \& General Workers Union $(\mathrm{T} \& \mathrm{G})$ in Britain. Hence the preparation of trade unionists via workers' education programmes through the Reggie Miller Foundation (the GWU's Adult Education agency which, with its vast array of programmes, is arguably the largest non-vocational adult education entity in Malta) or the Centre for Labour studies (CLS) at the University of Malta must also aim for flexible specialization, that recurring theme throughout this paper. Tool courses for shop stewards and union personnel, as well as employees in general, should 
equip learners with a vast array of skills and knowledge to enable them to perform a variety of tasks effectively, imaginatively and in an informed manner.

The demands for economic development and work opportunities need to be balanced by environmental concerns in a process of sustainable development. It is to this aspect of adult education in small states that the paper now turns.

\section{Adult Education for Sustainable Development}

Due to the diverse competing demands for land use, Malta, which is densely populated (a situation shared with Singapore and with such autonomous jurisdictions as Gibraltar and Bermuda), is more intimately dependent, for its development, on its limited resources than larger states. Quite logically the need to focus on sustainable development, that is balancing economic, social and environmental concerns so as to ensure equitable and continued development (UNCED, 1992; United Nations, 2002), has always constituted the main theme in development strategies of small island states (United Nations, 1994; United Nations, 2005). Nevertheless, the ingrained cultural conceptions of what constitutes the good life, forged by years of colonialism and the flood of overt and covert messages conveyed by the media, militate against this drive. Unsustainable lifestyles, characterised by the irresponsible squandering of resources, are portrayed as a welcomed escapism from the worries of having to eke out a living that have plagued these states for several years.

\section{Tourism and Sustainable Development}

This phenomenon is evident throughout Malta's efforts to boost its tourism industry. In an effort to diversify its economy, Malta invested heavily in the tourism industry, as is typical of small island states for reasons identified earlier on. Since its 
humble beginnings in the 1950s this industry has grown to such an extent that it accounted for about $15 \%$ of the GDP in 2001 (the contribution reached the $23 \%$ mark in 1994) - and all this without considering any of the indirect ancillary employments and commerce that tourism generates. Figures for 2004 show that the influx of tourists during that year increased the country's already high population density by $8 \%$ (MEPA, 2006).

To meet the needs of this rapidly expanding industry, several hotel building projects were embarked upon and these projects rapidly ate away at most of the country's coast and other scenic areas, destroying unique spots of the nation's natural capital as well as forever altering the social and cultural structures of the communities living in these areas. This development was so rapid that the country's infrastructure could not satisfy the increased demands for energy and water leading to regulatory measures that had a negative impact on the quality of life of the citizens. Even the solid waste and sewerage systems were stretched beyond their limits.

\section{Killing the goose that lays the golden eggs}

As the numbers of tourists seemed to have reached a maximum in the $90 \mathrm{~s}$, questions regarding why these numbers failed to keep on increasing were raised. Studies (e.g. Briguglio et al., 1996a; Briguglio et al., 1996b) seemed to indicate that unsustainable development was impacting negatively on the industry. In other words, the uncontrolled development was degrading and hence lowered the quality of the very same product that sustained it - it was killing the golden goose! To counter this trend, the Malta Tourism Authority (2001) carried out a study in an effort to identify Malta's tourist carrying capacity - but the report provided only a partial analysis of the situation, where 
the concerns were mainly with economic and social matters while little consideration was given to the country's national resources.

In 2006 the Malta Tourism Authority (MTA) launched, for public consultation, its proposed strategic plan for 2006-2009. Despite international trends (e.g. World Tourism Organisation, 1999), the word "sustainable" only features four times in the entire document and understandably the issue of sustainable tourism is not explored as sufficiently as other issues, particularly the marketing issue. Despite using the word "sustainable" in its Mission Statement, MTA uses the term in a such way that it seems to refer to the growth of the tourism industry. In another part of the document, the MTA fails to consider the natural environment as an essential component of Malta's heritage. Besides serving as another indication of the lack of understanding of the principles of sustainable development and their implications for the industry, this omission underscores the tourism industry's deep rooted tendency to take the natural environment for granted and to consider it as its expendable commodity.

This proposed strategy seems to have been replaced by an overarching Tourism Policy (Ministry for Tourism and Culture, 2006) that rectifies all these incongruencies giving sustainable development its due consideration and also placing its operation within the framework of the National Sustainable Development Strategy (National Commission for Sustainable Development, 2006). Only time can tell, however, whether these considerations are mere rhetoric or whether the principles of sustainable development have finally found their place in the tourism industry's modus operandi.

\section{Economy, Society, Environment}


The aim of this relatively lengthy treatise of the state of sustainable development in the Maltese tourism industry is to demonstrate that, no matter how much the importance of sustainable development for the survival of small states is stressed in international fora, it is still an uphill struggle to gain recognition at the national level. Although it has become a diplomatic requirement to feature the three-pillar paradigm of sustainable development (economy - society - environment) in national policy documents, its translation into national practice still leaves much to be desired. The three pillars of sustainable development are not a national reality. The economic dimension still draws most of the state's attention, followed by the social dimension, with environmental concerns being given lip service. The affirmation of sustainable development principles is conceived of as an attempt to obstruct development. These principles are therefore sacrificed for economic gains when these are placed on the bargaining table.

Malta still seems prone to non-sustainable economic proposals because of its economic development requirements and the ingrained "beggars can't be choosers" mentality that focuses on the economic gains of development proposals but disregards the price that the island will have to pay in terms of its resources. This phenomenon is clearly shown by the growth of the construction and quarrying sector despite its overall negative environmental impact. Besides causing the rapid depletion of limestone, one of the few natural resources of the island, the sector is responsible for $88 \%$ of Malta's solid waste. Even though around 35,000 dwellings (23\% of the total) are vacant, this sector's contribution to $5.3 \%$ of the GDP ensures that no brakes are applied to the construction of buildings (MEPA, 2006). 
Lacking a clear vision of what sustainable development implies and a strong conviction that it can deliver on what it promises, policy makers are quite vulnerable to these short-term unsustainable proposals. The responsibility of keeping a watchful eye on unsustainable development is placed squarely on NGOs. The general public is usually left at a cross-road: undecided over such issues. Should they support an unsustainable development project because of its economic returns? Alternatively, should they oppose it because of the negative impact it will have on the nation's ecological and social fabric? This is where education for sustainable development (ESD) becomes important. Among other things, it entails enabling citizens to (i) understand the various implications of sustainable development; (ii) be equipped with the skills to participate in decision making fora, and (iii) develop the right attitudes and values that prompt them to take action, both at the personal and communal levels.

The UN World Summit on Environment and Development (UNCED, 1992) considers ESD as critical "for promoting sustainable development and improving the capacity of the people to address environment and development issues" (Chapter 36, 36.3). Inherent in this statement is the central role that citizens have to play in implementing sustainable development. This is the distinguishing feature of Agenda 21. The milestone publication "Caring for the Earth: a Strategy for Sustainable Living" maintains that a sustainable society could be achieved through the following actions:

- Changing personal attitudes and practices;

- Enabling communities to care for their own environments;

- Providing a national framework for integrating development and conservation; and

- Creating a global alliance (IUCN/UNEP/ WWF, 1991). 
Based on these recommendations, an adult ESD programme should therefore help the learner deal with sustainable development principles on two fronts: (i) in his/her personal lifestyle choices, and (ii) in the context within which s/he lives and works. These proposed actions also assume a national supporting infrastructure that would facilitate the achievement of targets set by the international community. The following sections will examine the extent to which these recommendations are being addressed in Malta and related issues.

The slow implementation of sustainable development has been attributed to a general lack of political will (United Nations, 2002), as already indicated. Consequently ESD tends to share the same fate. Given that the need for ESD is still to be acknowledged, one can only imagine where adult ESD features in the policy makers' priority list. The following is a brief review of the major interrelated misconceptions that plague the implementation of adult ESD:

a. Failure to understand what ESD (and consequently adult ESD) entails. Although most policy makers might be familiar with its affective objectives, they are still unclear about how these can be achieved (Pace, 1992). As a result they either fail to make the right decisions for its implementation or fail to see its role when drafting policies. For example, while the importance of ongoing educational programmes to support the Solid Waste Management Strategy was acknowledged, the strategy failed to include the proposal of a credible plan of action for education and to allot funds for it (Ministry for the Environment, 2001).

b. This lack of awareness has been compounded by protracted academic debates about terminology. Ever since it was first referred to as Environmental Education (IUCN, 1970), different authors sought to gain academic mileage by justifying alternative terms for it. The literature abounds with these terms - and while the subtleties implied by them might titillate academics and researchers in the field, they generate confusion in policy makers who do not have the time to enter into these restricted debates (Leal Filho \& Pace, 2006). In countries (particularly small states) where governments have other more urgent socio-economic priorities to address, dealing with these trivial issues is seen as a waste of precious time and ESD matters are placed once again on the backburner - irrespective of the years 
of negotiation spent in obtaining recognition (Leal Filho, 1996; Smyth, 2002). Moreover, keeping up with the change in terms creates an uncalled-for burden on the small state's already stretched ESD specialists.

c. Because sustainable development issues are most frequently interpreted as purely ecological concerns, a large proportion of the educational programmes on offer traditionally equate ESD with the acquisition of environmental scientific knowledge with little if any reference made to the cultural and social dimensions (Pace, 1992). Such programmes perpetuate a fragmentary approach to the resolution of development issues - a fallacy that continues to alienate people from sustainable development. Addressing developmental issues from a holistic perspective is particularly vital in the context of small states where issues involving the three pillars of sustainable development are a regular daily concern.

d. Policy makers, who are not aware of the implications of sustainable development, usually make the wrong assumption that ESD involves just the imparting of knowledge and that sustainable values are an automatic natural consequence of this increased awareness. Consequently (as in the case of Malta) the state's commitment towards ESD is measured by the amount of environmental topics featured in the curricula of educational programmes (National Commission for Sustainable Development, 2006).

A review of the available syllabi clearly indicates that topics relating to the Maltese environment are treated during all the years of formal education possibly as a result of the setting up of the local Matriculation and Secondary Education Certificate (MATSEC) Examinations Board in June 1992. However, closer examination reveals a vain repetition, one scholastic year after another, of issues that are not necessarily the most relevant environmental issues for the Maltese Islands (Pace, 1997). Moreover, Abela (1993) shows that while Maltese people are aware of environmental problems, their level of awareness is very superficial and lacks internalisation. Attitudes and values are not adequately developed and pro-environmental action is somewhat lacking.

e. One issue that specifically concerns adult education is the ingrained conviction that ESD programmes for adults are a waste of time. In a survey among educators from different levels of the Maltese formal educational system, Pace (2000) reports that respondents viewed environmental adult education only as a complement to environmental education initiatives in schools. Preparing a new generation of environmentally responsible citizens was preferred, by the majority of the respondents, to the seemingly impossible task of educating adults who, we were told, are "already set in their ways". 
It is no wonder, considering all these obstacles, that to date Malta does not have a formal national ESD policy and adult ESD programmes are practically non existent. Any adult education campaigns related to sustainable development issues are usually organised by pressure groups on a communal basis in times of crises, i.e. when development threatens the environment of the community (Calleja \& Ellul, 2007; Cilia, 2005; Psaila, 2004). Consequently adult ESD initiatives tend to be sporadic and disjointed with a considerable degree of repetition and waste of resources; they are also short-lived.

Along the years there have been two notable attempts at developing an ESD policy - but neither was successful:

- In 1995 a task group was set up to develop the National Environmental Education Strategy (NEES). NEES was to "... focus its action on the formal and informal sectors of education with the goal of directing educational processes towards the development of a new environmental ethic - education for sustainability." (Pace \& Caruana, 2004). NEES initiated consultation meetings with various target sectors of Maltese society, but the NEES process required a level of commitment towards sustainable development that was not reflected in the 'felt' needs of the target organisations and the authorities. Consequently, rather than a strategy - as was originally conceived - NEES ended up proposing a discussion document which was also to serve as a primer that initiated a structured debate on ESD.

- 1996 saw a unique development in Maltese educational history - the revision of the National Minimum Curriculum (NMC). For the first time, curriculum innovation was being presented within a holistic framework of guidelines coupled with the respective support infrastructure required. Moreover, the process involved a wide consultation exercise with a variety of stakeholders. With its advocacy of an interdisciplinary approach, support for learner-centred and experiential learning, and commitment to the development of independent critical learners, the NMC seemed to provide the ideal opportunity to introduce ESD. However, despite attempts made by different organisations during the consultation phase to achieve this, the document, published just a few years after the Rio Earth Summit and at the turn of the Millennium, failed to mention sustainable development (let alone introduce ESD) except for the following sentence:

"One ought also to promote the view that the sustainability of life on earth is contingent on our everyday choices" (Ministry of Education, 1999, p. 27) 
Mainly in response to pressures resulting from international commitments, however, the authorities seem to be moving in the right direction. In view of the Environment Protection Act (Laws of Malta, 2007, Act No. XX, 2001), the Maltese Government set up the National Commission for Sustainable Development with the specific brief of initiating a national debate that would lead to the formulation of the

National Sustainable Development Strategy (National Commission for Sustainable Development, 2006). The Commission acknowledged the importance of ESD from the onset of the process. Consequently ESD features throughout the strategy, with adult ESD being proposed for different sectors of society. The next important development, i.e. the implementation of the strategy, would ensure that these recommendations are put into practice. In the context of adult ESD, the implementation of the strategic directions would need to consider the following:

\section{a. The nature of the programmes offered}

Adults are not oversized children and therefore the content matter and the methodology adopted during the adult education programmes should match their cognitive levels and address their learning needs and styles - this is particularly true of adult ESD. At times, ESD is trivialised through the presentation of childish issues with childish solutions, with the result that adults are not engaged in the learning process and the educational targets are not reached. This might explain why, although the "Keep Malta Tidy" campaign, launched in the 60 s to promote cleanliness, is still operational, albeit under various guises, its effectiveness in achieving its goals leaves a lot to be desired. 
Given the ESD's aims, what is needed is not just a rethink of the knowledge component of educational programmes but a radical restructuring of traditional educational practices in order to facilitate the introduction of participatory and creative ways of learning pedagogies. These pedagogies would enable learners to develop skills, attitudes and values that are conducive to sustainable lifestyles.

Adult ESD should provide learners with active knowledge that reflects their realities and is relevant to their experiences - even if these mean involving the learners in the design of their learning programme (Enriquez, 1999). This also means the adoption of issue-oriented and problem-solving pedagogies that familiarise adults with the multifaceted nature of sustainable development issues and help them in the seeking of sustainable solutions.

Moreover, adult ESD programmes should provide adults with the opportunity of reviewing their attitudes and values in relation to sustainable development principles. This is a necessary dimension if the target of these educational programmes is the adoption of sustainable lifestyles and decision making. In other words, ESD programmes should help learners to identify any dissonance between their espoused values and the actual values that govern their day to day actions.

\section{b. Enabling public participation}

Like other small states, Malta's administrative and educational structures have been scarred by its very long history of colonialism. Several years of colonialism have steadily alienated the local population from their responsibilities towards their surroundings by systematically narrowing their conception of "my environment". Colonial rule effectively led locals to adopt a reductionist view of "my surroundings" 
reducing it to just "my home". What lay outside their doors was not theirs - it was their master's - and consequently the welfare of the "outside" environment was the current ruler's responsibility. After more than 40 years as an independent nation, a significant number of Maltese still regard environmental responsibility the same way (Pace, 2007; Abela, 1993). Unfortunately educational institutions have tended to reproduce this state of affairs.

In contrast, ESD strives to develop a citizenry that is empowered to actively participate in the decision making fora that determine its quality of life. Instead of being moulded into conforming as unthinking adults that are susceptible to the whims of policy makers, adult ESD learners are gradually changed into active political beings (Freire, 1970). The goals of sustainable development can only be achieved through this active participation of individuals.

Nevertheless, public participation in decision making is not solely dependent on the availability of ESD programmes. Care must be taken to ensure that decision-making fora relating (for example) to the approval of development projects are truly 'open' to public consultation and participation. The choice of venue for the meeting, the language used, and the dress code of the participants are all details that need to be looked into to ensure that no one feels excluded. However, there are still two issues that could hinder participation. The vast majority of the public lack the necessary skills to interpret the technical data presented in the reports and to organise themselves into effective pressure groups. Provision of adult ESD needs to consider ways how these two obstacles are surmounted - otherwise there is the risk that individuals feel much more frustrated than empowered. 


\section{c. Providers of adult ESD}

Adult ESD needs to address all sectors of society and hence it has to involve different stakeholders (UNESCO Institute for Education, 1999). Any initiative aimed to provide adult ESD programmes needs to ensure that the providers of this service are adequately prepared.

The media are a major potential provider of ESD that would successfully address different sectors while bringing together different stakeholders. Unfortunately in Malta this resource is underutilized. The reason is threefold: (i) a lack of trained personnel ; they cannot be spared for training, (ii) the fact that sustainable development issues 'don't sell' and capital gain is what makes the wheels turn in media houses, and (iii) sustainable development issues usually entail everyday decision making that is not dramatic or sensational enough to have airing value.

We have seen, in the first section, how, traditionally, most of the adult educators are teachers. Currently, the Faculty of Education (the major teacher pre-service education institution on the island) does not have an ESD policy that would ensure that every graduate teacher would have received training in the area. Nevertheless, the Centre for Environmental Education \& Research (CEER) is systematically targeting studentteachers by offering ESD study units in which the personal development of prosustainable development values is an integral feature of the course. Given that in small states, teachers perform multifunctional roles, then the result of this effort might serve different and complementary purposes, including adult education purposes. 
Currently, the University of Malta has a monopoly over ESD provision since the people who are qualified to train individuals in ESD are to be found in CEER. Rather than hinder the development of ESD, this monopoly serves to unite the initiatives in ESD by presenting a coherent national vision of what it means (Pace, 1997; Tanti, 2000). Moreover, in the context of a small state, CEER acted as a reference point that was instrumental in the introduction of ESD at policy making level. This concentration also signifies a pooling of resources in a small state where, we reiterate, duplication is wasteful and costly. This is one of the leitmotifs throughout this discussion of adult education in a small state island context, a discussion which underscores the need for imaginative ways of going about the task of educating adults, ways that take into consideration the small scale dimension of the country and which ensure that the characteristics of smallness are not constraints but strengths.

\section{Notes}

\footnotetext{
1 International Council of Adult Education

2 Information obtained from Dr Didacus Jules, retired former Permanent Secretary, Ministry of Education, St Lucia and Coordinator of the Grenada literacy campaign under the Bishop government in the 80 s.

3 This has implications for adult literacy efforts in microstates where programmes in the indigenous language do not have the same backing, in terms of the provision of a resource centre, as would be the case with regard to programmes in foreign languages. The centres in the latter case are wholly or partly financed by the foreign countries concerned. (see Mayo, 1994)

4 Information obtained through electronic communication from Dr Didacus Jules, Wednesday 22nd August 2007.

5 Electronic correspondence with Klitos Symeonides, former Adult Education director, Cyprus and Dr Didacus Jules, former Perman ent Secretary for Education, St. Lucia.

6 Observation by one of the authors at the Paulo Freire Institute in the summer of 2000.

7 see the following European Prison Education Association website: http://www.epea.org/

8 Taped interview with Dr Anthony Vella, one of the coordinators of the prison education programme at the University of Malta.

9 ibid

10 Such a body is currently being proposed in Malta through amendments to the Education Act.
}

\section{References}

ABELA, A.M. (1993) Surveys of values in Malta. Politika. Pieta, (Malta: Partit Nazzjonalista). 
BALDACCHINO, G, (1993) Bursting the Bubble: The Pseudo-Development Strategies of Microstates. Development and Change, 24, 29 - 51.

BALDACCHINO, G and MAYO, P (1995), 'Multifunctionalism, Volunteers and the School Culture - Adult Education in the Maltese Context.' In Joachim Knoll (ed.), International Yearbook of Adult Education, (Bochum, University of the Ruhr).

BALDACCHINO, G and MAYO, P (1996) 'Adult Continuing Education in Small and Island States. The Case of Malta.' Convergence, Vol. XX1X, No.2., pp. 22 - 35.

BALDACCHINO, G and MAYO, P (1997) 'Adult Learning in the Maltese Context. Editorial Introduction' In Godfrey Baldacchino and Peter Mayo (eds.)Beyond Schooling. Adult Education in Malta, Malta, Mireva.

BORG, C and MAYO, P (2001a) 'Malta', co-authored with Carmel Borg. In Alan Chadwick and Annette Stannett (eds.), Museums and Adults Learning . Perspectives from Europe, Leicester: NIACE.

BORG, C and MAYO, P (2001b) ' Maltese Museums, Adult Education and Cultural Politics' (co-authored with Carmel Borg) in Education and Society, 18/3, pp. 77 - 97.

BORG, C and MAYO, P (2006a), 'Towards an Anti-Racist Agenda in Education. The Case of. In Donaldo Macedo and Panagiota Gounari (Eds.), The Globalization of Racism, (Boulder, Paradigm Publishers).

BORG, C and MAYO, P (2006b), Learning and Social Difference. Challenges for Public Education and Critical Pedagogy, (Boulder, Paradigm).

BORG, C and MAYO, P (2007), Public Intellectuals, Radical Democracy and Social Movements, (New York, Peter Lang).

BORG, C., CAUCHI, B. \& MAYO, P. (2003)'Museums Education and Cultural Contestation' (co-authored with Carmel Borg and Bernard Cauchi) in Journal of Mediterranean Studies 13 (1) pp. 89-108.

BRAY, M. (1991), Making Small Practical. The Organisation and Management of Ministries of Education in Small States, (London, Commonwealth Secretariat).

BRIGUGLIO L., BUTLER R., HARRISON D. \& LEAL FILHO, W. (1996a) Sustainable Tourism in Islands and Small States: Case Studies. (London, Cassell/Pinter).

BRIGUGLIO L., ARCHER B. \& JAARI J. (1996b) Sustainable Tourism in Islands and Small States: Issues and Policies (London, Cassell/Pinter).

BROCK, C (1988), 'Education and National Scale: The World of Small States', Prospects, 18 (3), pp. 303-314. 
CALlEJA, M ( 2006), 'The Correctional Mirror - Lifelong Learning in a Correctional Facility in Malta' in European Lifelong Learning. The Manager's Handbook, EULLearN http://distance.ktu.It/thenuce/ebook2006/Chapter_1/69246.html Accessed $24^{\text {th }}$ August, 2007

CALLEJA, V. \& ELLUL, A. (2007) The Interim Landfills Issue: Educating the Grassroots Movement. Unpublished B.Ed. (Hons) dissertation. Faculty of Education, University of Malta.

CARDONA, M (2000), 'Il Tema della Learning Region. Il Caso di Malta'(The Learning Region Theme: The Case of Malta), unpublished thesis, laurea course in Scienze dell'Educazione, Universita` degli Studi di Roma III.

CEC (2000), Commission Staff Working Paper. A Memorandum on Lifelong Learning, (Brussels, European Commission).

CHADWICK, A and STANNETT, A, (Eds.) (1995), Museum and the Education of Adults, (Leicester, NIACE).

CHADWICK, A and STANNETT, A. (Eds.) (2000) Museums and Adults Learning: Perspectives from Europe, (Leicester, NIACE).

CILIA, R. (2005) Empowering Citizens Through Environmental Education: the Fgura Case Study. Unpublished B.Ed. (Hons) dissertation. Faculty of Education, University of Malta.

DE SIQUERIA, A.C (2005), 'The Regulation of Education through the WTO/GATS' in Journal for Critical Education Policy Studies, 3 (1), http://www.jceps.com/?pageID=article\&articleID=41 Accessed 24 ${ }^{\text {th }}$ August, 2007.

EMPLOYMENT AND TRAIING CORPORATION (2003), A Human Resource Development Policy and Strategy for Malta: 2004-2006, (Malta, Employment and Training Corporation).

ENRIQUEZ, S (1995), ‘A Critical Analysis of a Women's Adult Education Programme in Malta', unpublished B.Ed. Hons thesis, University of Malta.

ENRIQUEZ, S. (1999) Environmental Education With, By and For Women. Unpublished M.Ed. dissertation. Faculty of Education, University of Malta.

FALZON, P.A \& BUSUTTIL, J (1988), 'Private Tuition in Malta. A hidden Educational Phenomenon Revealed', unpublished B.Ed (Hons.) dissertation, University of Malta.

FARRUGIA, C.J (2007), 'The Rewards and Tribulations of Senior Education Managers in Small States' in DARMANIN, M and MAYO, P (Eds.), Education, Society and Leadership, (Malta, Allied Publications Ltd).

FARRUGIA, C.J and ATTARD, P. A (1989), The multifunctional Administrator, (London, Commonwealth Secretariat). 
FORUM FOR A BETTER ECONOMY (1988). Value 2000 . Report (Malta, Department of Information):

FREIRE, P. (1970). Pedagogy of the Oppressed. (New York, New Seabury Press).

FREIRE, P. (1976) Literacy and the possible dream. Prospects , 6, 68-71

GELPI, E. (2002), Lavoro Futuro. La formazione professionale come progetto politico, (Milan, Edizioni Angelo Guerini e Associati SpA).

HILL, D and ASSOCIATES (2005), 'Education Services Liberalisation' in ROSSKAM, E (ed.), Winners or Losers? Liberalizing Public Services, (Geneva, International Labour Office).

HOOPER-GREENHILL, E. 1995. A Museum Educator's Perspective, in Chadwick, A and Stannett, A (Eds.), Museum and the Education of Adults, (Leicester, NIACE).

HORTON, M and FREIRE, P (1990), We make the road by walking. Conversations on education and social change, (Philadelphia, Temple University Press).

ILLICH, I and VERNE, E. (1976), Imprisoned in the Global Classroom, (Montreal, Writers and Readers Publishing Cooperative).

IUCN (1970) International Working Meeting on Environmental Education in the School Curriculum, Final Report, September, 1980. (USA, IUCN).

IUCN/UNEP/WWF (1991) Caring for the Earth. Strategy for Sustainable Living. Gland, Switzerland.

JULES, D. (1994/5), 'Adult Education Policy in Micro-States. The Case of the Caribbean' in Policy Studies Review, 13 (3 and 4).

LAWS OF MALTA (2007) Chapter 435: Environment Protection Act. Part IV. Ministry for Justice and Home Affairs, Malta. [On-line] http://docs.justice.gov.mt/lom/legislation/english/leg/vol_13/chapt435.pdf. Accessed on August 2007.

LEAL FILHO, W. (1996) "Furthering environmental education". In LEAL FILHO, W.; MURPHY, Z. and O'LOAN K. (eds.) A Sourcebook for Environmental Education: a Practical Review Based on the Belgrade Charter. (London, The Parthenon Publishing Group).

LEAL FILHO, W. and PACE, P. (2006) The UN Decade of Education for Sustainable Development: meeting the challenges or another missed opportunity? In Manolas, E.I. (ed.) Sustainable Management and Development of Mountainous and Island Areas. Vol.1. Media, University of Crete, Greece.

MALTA TOURISM AUTHORITY (2001) Carrying Capacity Assessment for Tourism in the Maltese Islands. (Malta, Ministry of Tourism).

MALTA TOURISM AUTHORITY (2006) National and Strategic Plan for the Malta Tourism Authority (MTA) for the years 2006-2009. (Malta, Malta Tourism Authority). 
MALTA ENVIRONMENT AND PLANNING AUTHORITY (MEPA) (2006) State of the Environment Report: 2005. (Malta, Malta Environment and Planning Authority).

MAYO, P (1994), 'Adult Literacy Programmes in Malta - A Critical Review.' Language and Education, 8 (1 and 2), pp. 31-39.

MAYO, P (2007), Adult Education in Malta, (Bonn, IIZ-DVV).

MAYO, P and BRIGUGLIO, L (Eds.) (1996) Special issue on Adult Continuing Education in Small States and Islands, Convergence, 29(2).

MINISTRY OF EDUCATION (1999). Creating the Future Together. (Malta, Ministry of Education).

MINISTRY FOR THE ENVIRONMENT (2001) A Solid Waste Management Strategy for the Maltese Islands. (Malta, Office of the Director General, Works Division) Floriana.

MINISTRY FOR TOURISM AND CULTURE (2006) Tourism Policy for the Maltese Islands 2007-2011 Draft for External Consultation. (Malta,Ministry for Tourism and Culture).

NATIONAL COMMISSION FOR SUSTAINABLE DEVELOPMENT (2006) A Sustainable Development Strategy for the Maltese Islands. 2006-2016, (Malta, National Commission for Sustainable Development).

PACE, P. (1992) The Environmental Education Programme - a Curriculum Development Project for the Primary School. Unpublished M.Ed. dissertation. Faculty of Education, University of Malta.

PACE, P. (1997) Environmental education in Malta trends and challenges. Environmental Education Research. 3(1), pp.69-82.

PACE P. (2000) Attitudes towards environmental education in the Maltese formal education system. In LEAL FILHO, W. (ed.) Communicating Sustainability.

Environmental Education, Communication and Sustainability Series No. 8. Peter Lang Scientific Publishers, Frankfurt, Germany.

PACE, P. (2007) Empowering citizens through education for sustainable development. In XUEREB, P.G. (ed,) Business Ethics and Religious Values in the European Union and Malta - for a Moral Level Playing Field. Civil Society Project Report 2007. (Malta, The European Documentation \& Research Centre, University of Malta).

PACE, P. and CARUANA, V. (2004) The National Environmental Education Strategy: Discussion Policy Document (Malta, Ministry for Rural Affairs and Environment)

PSAILA, A. (2004) The Cement Factory Issue: a Grassroots Movement in Malta. Unpublished B.Ed. (Hons) dissertation. Faculty of Education, University of Malta.

ROGERS, A (1996), 'Adult Continuing Education in Small States and Islands: Concept Paper' in Convergence, 29(2), pp. 8-21.

SULTANA, R.G and BALDACCHINO, G (1994) 'Introduction' in SULTANA, R.G and BALDACCHINO, (Eds.), Maltese Society. A Sociological Inquiry, (Malta, Mireva). 
SMYTH, J.C. (2002) Are Educators Ready for the Next Earth Summit? Millennium Papers Series, Issue 6. (London, Stakeholder Forum for Our Common Future).

SYMEONIDES, K (1992), 'Cyprus' in JARVIS, P (Ed.), Perspectives on Adult Education and Training in Europe, (Leicester, NIACE).

SYMEONIDES, K (2004), 'Adult Education in Cyprus' in CARUANA, D and MAYO, P (Eds.), Lifelong Learning in the Mediterranean, (Bonn, IIZ-DVV).

TANTI, V.M. (2000) Environmental Education in Maltese Government Schools: A Historical Review. Unpublished B.Ed. (Hons.) dissertation. Faculty of Education, University of Malta.

UNCED (1992) The United Nations Conference on Environment and Development: A Guide to Agenda 21. (Geneva, UN Publications Office).

UNITED NATIONS (1994) Report of the Global Conference on the Sustainable Development of Small Island Developing States. Bridgetown, Barbados, 25 April-6 May 1994 (New York, United Nations).

UNITED NATIONS (2002) Report of the World Summit on Sustainable Development. Johannesburg, South Africa, 26 August - 4 September 2002. (New York, United Nations).

UNITED NATIONS (2005) Report of the International Meeting to Review the Implementation of the Programme of Action for the Sustainable Development of Small Island Developing States. Port Louis, Mauritius, 10-14 January 2005 (New York, United Nations).

UNESCO INSTITUTE FOR EDUCATION (1999) Adult environmental education: awareness and environmental action Fifth International Conference on Adult Education (CONFINTEA V) Booklet 6a. (Hamburg, UNESCO).

VERGER, A and BONAL, X (2006), 'Against GATS: the Sense of a Global Struggle' in Journal for Critical Education Policy Studies, 4(1),

http://www.jceps.com/?pageID=article\&articleID=55 Accessed 24 ${ }^{\text {th }}$ August 2007

WALTERS, S. (Ed.) (1997), Globalization, Adult Education and Training. Impact and Issues, (London and New York, Zed Books; Leicester, NIACE).

WORLD TOURISM ORGANISATION (1999). Sustainable Development of Tourism. World Tourism Organisation. 